\title{
SYMPTOMATIC HYDROCEPHALUS IN A NEWBORN INFECTED WITH LISTERIA MONOCYTOGENES
}

\author{
Analía L. Laciar ${ }^{1 *}$; Raúl P. Hasuoka ${ }^{2}$; Silvia M. Correa²; Alicia M. Miranda²; Olga N.P. Centorbi ${ }^{1}$ \\ ${ }^{1}$ Area Microbiología, Universidad Nacional de San Luis, San Luis, Argentina. ${ }^{2}$ Hospital Policlínico Regional, San Luis, Argentina.
}

Submitted: October 15, 1998; Returned to authors for corrections: January 28, 1999; Approved: February 16, 2000

\section{SHORT COMMUNICATION}

\begin{abstract}
Central nervous system infections caused by Listeria monocytogenes produce a wide range of clinical symptoms which include cerebral abscesses, meningitis and nonmeningitic parenchymal cerebritis. A case study is presented of early listeriosis with signs of meningitis accompanied with septicemia and complicated with severe hydrocephalus.
\end{abstract}

Key words: Listeria monocytogenes, meningitis, septicemia, hydrocephalus.

The first reported case of human infection by Listeria monocytogenes took place in 1921 and since then listeriosis has been recognized as a rare though frequently fatal bacterial disease (5). Elderly, immunocompromised, pregnant and neonate subjects are the most seriously affected ones.

In pregnant women it usually appears in the form of mild influenza-like symptoms which disappear with no treatment but can cause severe fetal and neonatal infections with abortion rates of over $20 \%$ (11).

Intrauterine infection, in most cases, arises as a consequence of transplacental spread after mother's bacteraemia, though in some cases it can be due to ascendent spread from the mother's lower genital tract colonized by L. monocytogenes.

A study carried out in Argentina showed $78.6 \%$ of mortality in infected newborns, a rate which is much higher than that reported in the literature (9). This could be attributed to the fact that the diagnosed cases corresponded to the form precocious start, this is to say, to children with septicemia.

The patient was a limit preterm newborn (born on the 37th week), of normal weight for gestational age $(2,640 \mathrm{~g})$, born by vaginal delivery, cephalic presentation, with artificial rupture of membrane intra-partum, meconial amniotic liquid, and Apgar
0/6. She required type IV animation (intubation). She entered the Neonatal Intensive Care Unit in incubator with mechanical respiratory assistance and presenting symptoms compatible with precocious neonatal sepsis and petechial lesions on her face, trunk and abdomen, which disappeared after 24 hours. Her liver was palpable at $2-3 \mathrm{~cm}$ from the costal rim and spleen end. She presented extreme bradycardia though cardiac murmur was not auscultated.

A treatment with ampicillin (100 $\mathrm{mg} / \mathrm{kg} / \mathrm{day})$, gentamicin (3 $\mathrm{mg} / \mathrm{kg} /$ day) and dopamin $(5 \mu \mathrm{g} / \mathrm{min}$ ) was started.

Laboratory data reported a pathologic blood count with a white blood cell count of $10,600 \mathrm{cel} / \mathrm{mm}^{3}$, while CSF was opalescent and xanthochromic with $70 \mathrm{mg} / \mathrm{dl}$ of proteins, hypoglucorrachia, and $2,200 \mathrm{cel} / \mathrm{mm}^{3}$ with predominance of polymorphonuclears $(82 \%)$.

Due to the presence of Gram positive coccobacilli in the CSF by Gram's stain, the dose of ampicillin was duplicate.

Twelve hours later the patient started to show generalized tonic-clonic convulsions and fever, upon which phenobarbital was administered.

Both the CSF and the haemoculture were positive for $L$. monocytogenes, sensitive to penicillin G, ampicillin,

\footnotetext{
* Corresponding author. Mailing address: Chacabuco y Pedernera, 5700, San Luís, Argentina. Fax: (+54) 2652-431301
} 
tetracycline, chloramphenicol and gentamicin, while resistant to cefuroxim and cefoxitin.

L. monocytogenes was also isolated from the mother's vagina after delivery. Identification was carried out by cultural and biochemical properties according to methods described in previous works (10). Subsequently, the experimental pathogenicity was determined in mice (6); the characterization by pulsed field gel electrophoresis (restriction of the endonucleases: Apa I and Sma I) (Fig. 1) and phage-typing was performed by Dr. J. Rocourt of the Pasteur Institut (Paris, France) (3). The same strain of L. monocytogenes was detected in all samples and it was identified as serovar $4 \mathrm{~b}$ and lysovar 3552/ 1444/2671.

Cerebral sonographies performed on the 24th hour and 5th day of life were normal. Respiratory assistance was then interrupted and the patient was fed nasogastrically with maternal milk. Two days later, haemocultures and CSF's cultures were negative but on day 17 a cerebral sonography revealed bilateral enlargement of ventricles III and IV with caudated images compatible with paraencephalia.

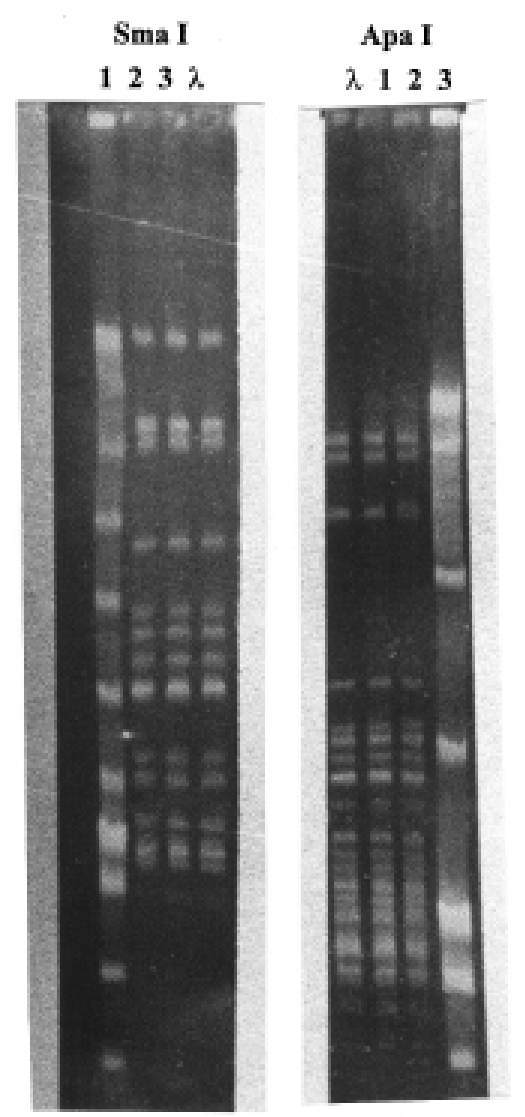

Figure 1. Strain characterization by pulsed field gel electrophoresis (restriction endonucleases: Apa I and Sma I). 1: L. monocytogenes strain from the mother's vagina; 2 and 3: L. monocytogenes strains from the newborn's blood and CSF, respectively; 1: lambda ladder standard.
The patient was discharged on day 22 and follow ups were maintained through the high-risk outpatient service, indicating continuation of treatment with phenobarbital. A computerized axial tomography performed on the third month of age revealed severe hydrocephalus which required insertion of a valve.

A marked increase of L. monocytogenes infections has been reported in the past years, particularly of early listeriosis with meningitis and septicemia, as in the case here reported, and with a high mortality.

The annual rate for Los Angeles (Unites States) was of 18.1 cases per 100,000 liveborns in the period 1986-1990, but decreased to 12.7 and 11.6 in 1991 and 1992, respectively (7).

Classical listeriosis usually affects subjects with predisposing factors, such as immunodeficiency. In the case reported here the mother, who was the cause of infection, did not present such factors. She reported, however, to have had influenza-like symptoms 15 or 20 days prior to delivery. Such symptoms did not require intensive treatment but probably corresponded to a bacteraemia phase followed by intrauterine spread of $L$. monocytogenes and transplacental transmission. This might also have been the cause for preterm delivery (three weeks before due). The evidence of intrauterine transmission was confirmed by the coincidence between the phenotypic characteristics, phage-patterns and the studies on pulse field gel electrophoresis.

The mother could have been carrier of the microorganisms, though the incidence of vaginal or intestinal carriage of $L$. monocytogenes has been reported to be low (5). Besides, it remains uncertain whether listeriosis is a significant cause of abortions. More detailed microbiological exams of aborted fetuses and preterm children could contribute to clarify such issue. The infection of this woman was probably of bovine origin, since she lived and worked in a dairy farm. The newborn presented a precocious sepsis with a meningoencephalic complication, confirmed by a $3 \mathrm{~cm}$ increase of her cephalic perimeter from the day of her birth up to the 14th day of life.

The transfontanelar sonography showed a significant increase of the lateral ventricles, the ventricle III and part of the ventricle IV. A peritoneal diversion valve was put and it had not been removed up to the writing of this report.

The usually recommended antibiotics for the treatment of the central nervous system (CNS) infections by $L$. monocytogenes are penicillin $\mathrm{G}$ or ampicillin $(2,4)$. A combination with an aminoglycoside has also been recommended due to its synergistic effect showed in vitro (2). The use of erythromycin, chloramphenicol and vancomycin in patients allergic to penicillin has given variable results. Cotrimoxazole is becoming of frequent use due to its good penetration into the CNS and the possibility of continuing treatment oraly (8).

The well-known resistance of this bacterium to cephalosporins (cefuroxim, cefoxitin and cefotaxim) rules out employment of such antibiotics in the treatment of listeriosis. 
Hydrocephalus and death have been reported in children receiving such medication (1).

Early detection and treatment of pregnant-associated listeriosis could be possible if all febrile episodes during pregnancy were evaluated by haemoculturing, the neurologic prognosis depending to a great degree on correct handling of the patient.

\section{RESUMO}

\section{Hidrocefalia sintomática em um recém-nascido infectado com Listeria monocytogenes}

As infecções do sistema nervoso central produzidas por Listeria monocytogenes provocam una grande variedade de sintomas clínicos que incluem abscessos cerebrais, meningites e cerebrites parenquimáticas não meningíticas. Apresenta-se um caso de listeriose precoce com sinais de meningite acompanhada de septicemia e agravado com hidrocefalia grave.

Palavras-chave: Listeria monocytogenes, meningite, septicemia, hidrocefalia.

\section{REFERENCES}

1. Allerberger F.; Guggenbichler J.P. Listeriosis in Austria. Report of an outbreak in 1986. Acta Microbiol. Hungarica. 36:149-152. 1989.

2. Armstrong D. In: Mandell G.L.; Douglas R.G. Jr.; Bennett J.E. (eds). Principles and practice of infectious diseases. $2^{\text {nd }}$. ed. John Willey, New York, 1985. p 1177-1182.

3. Brosch R.; Buchrieser C.; Rocourt J. Subtyping of Listeria monocytogenes serovar $4 \mathrm{~b}$ by use of low-frecuency-cleavage restriction endonucleases and pulsed field gel electrophoresis. Rev. Microbiol. 142:667-675. 1991.

4. Carvajal A.; Samuelsson S.; Rothgardt N.P.; Frederiksen W'. The treatment of Listeria monocytogenes infection in the central nervous system. Acta Microbiol. Hungarica. 36:159-163. 1989.

5. Jensen A. Listeria in faecal and genital specimens. Med. Microbiol. Lett. 2:125-130.1993

6. Lovett J. Isolation and identification of Listeria monocytogenes in dairy products. J. Assoc. Off. Anal. Chem. 71:658-660. 1988.

7. Mascola L.; Ewert D.P.; Eller A. Listeriosis: a previously unreported medical complication in women with multiple gestations. Am. J. Obstet. Gynecol. 170: 1328-1332. 1994.

8. Ortel S. Listeria-meningitis and septicemia in immunocompromised patients. Acta Microbiol. Hungarica. 36:153-157. 1989.

9. Paolasso R.W. Listeriosis en Córdoba (Argentina). Acta Bioq. Clin. Latinoamer. 15:581-584. 1981.

10. Picca S.M.; Stchigel A.M.; de Torres R.A. Caracteres mínimos para la identificación de Listeria monocytogenes "sensu stricto". Acta Bioq. Clin. Latinoamer. 26:57-71. 1992.

11. Schuchat A.; Swaminathan B.; Broome C.V. Epidemiology of human listeriosis. Clin. Microbiol. Rev. 4:160-183. 1991. 